\title{
Historiography of Shahabuddin Muhammad Zydari Nassavi: From Chronologist to Memoirist
}

\author{
Hassan Hazrati \\ University of Tehran, Iran
}

\section{Introduction}

The Mogul attack event left such a heavy impact on the Islamic society that the observers considered it impossible for the society to get rid of that situation. The unique Mogul plunder and demolition drew the attention of writers to record the great event or the Great Calamity.In fact, in a short period of four decades, four lasting works were created in the four corners of the Islamic world, preparing the grounds for flourishing of historiography of the Ilkhanid era. The following works were the pioneers of movement of historiography of seventh century hegira: Tarikh al-Kamil, written by Ibn Athir in Mosul (828 Hegira), Jalaluddin Sirat Mengborni written by Mohammad Zydari Nassavi Khorasani of Iran in Mosul (638 Hegira), Tabaqat Nasseri, written by Minhaj Siraj Jouzani Ghori of Iran in Delhi (655-658 Hegira) and Tarikh Jahangoshai written by Ata Malek Mohammad Joveini Khorasani of Iran (658 Hegira) in Baghdad. The four historians wrote their works under the influence of the Mogul inroad. However, their approaches to the Mogul inroad were different. Although there is a kind of closeness of geographical, and even ethic, dimensions among the three works, i.e. Al-Kamil, Sirat Jalaluddin Mengborniand Tarikh Jahanghoshai, their stances and approaches have undeniable differences. Ibn Athir was a historian who was an inactive observer and uninvolved in the conflict between the rival powers during the unfolding of the event. However, he was not impartial. Nassavi was an executive of the Khwarazmian camp and an anti-Mogul figure who was involved in political and even military struggles against the Moguls. Jouzani too was an anti-Mogul activist in Ghor, who had to flee to Delhi under their pressure. Joveini was an official of the Ilkhanid court administration. Despite the existence of some differences, common historical values and mindsets led to similar viewpoints among them. The objective of this paper is not to discuss the viewpoints and stances of the said historians rather attempts have been made to depict a picture of the context of historiography of the first half of seventh century hegira. The main focus of this paper is to shed light on 
the historiographicalmethod and insight of Nassavi, a link in the historiographical chain of this period.

The History of Nassavi is one of the last links of Iranian historiography in Arabic language, which has been largely influenced by its predecessor historiography style. However, it has some innovations is its approach and writing style. Hence, this paper is an attempt to explain Nassavi's historiography and his approach to history. In other words, the following questions will be discussed in this paper: what was the approach of Nassavi to history and how he turned the event into data? In what methodological context and intellectual attitude and in what trend has this change happened?

\section{Nassavi's Scientific Life and Writings}

In fact, no authentic information is available about Nassavi's scientific life, his knowledge and his teachers. However, his two valuable works indicate that he had good command of Arabic and Persian languages and had properly studied and understood the historical and literary works of the predecessors. Nassavi used to compose poems in Persian and English languages. According to Minavi, "besides being a master in writing Persian and Arabic prose and poetry, Nassavi enjoyed a poetic verve. He composed an ode on the eulogy of Jalaluddin in Akhlat; three verses of which were quoted in Nafsat al Masdour. Perhaps, like many other learned poets and writers of his time he used to compose poems in Arabic as well." (Earlier Sirat, Introduction, p. mj). Nassavi has left two historiographical works, but unfortunately no trace of his treatises is available to be compared with other treatises to asses his writing skills. Nevertheless, his historical work indicates that he has been a skillfulsecretaryor administrator with good command of Arabic and Persian languages.

The first work authored by Nassavi was Nafsat al Masdour in Persian (written in 652) with an embellished and intricate prose whose understanding is difficult for ordinary readers. The usage of a large number of Quranic verses (134 verses), Arabic verses (79 couplets), Persian verses (58), anecdotes and expressions (309), and Arabic verses (83) on the one hand is an indication of his extraordinary command of Persian and particularly Arabic literature and on the other shows his embellished writing style. The subject of Nafsatal Masdour is Nassavi's memoirs of the third period of his life as well as the social critique of his period. Writing of memoir in the style of Nafsat al Masdour or Bath al Shakwa has a long history in 
Iranian culture which can be called a personal resentment report. The first work of this type was that of Anushirvan bin Khalid Kashani written in Persian language which was later translated into Arabic language by Emaduddin Kateb Isfahani (Hassanzadeh, 2007). Contrary to resentments of Kashani, which was turned to administrative instructions for viziers from memoir writing; Nafsat al Masdour remained at the memoir writing level and concealed the nature of memoir writing by being enveloped in verbose and bombastic words and embellished prose.This was one of the reasons for lack of distinction of memoir-writing aspects of Nafsat al Masdour with preceding works to the extent that it has diverted from the framework of memoir-writing and has turned into a historiographical writing.

Bath al Shakwa of Ein ul Quzat Hamedani, except for a small part which deals with the imprisonment and trial of Ein ul Quzat, does not fit into the framework of memoir writing and is predominantly in the form of mystical complaints. It seems that in this work, Nassavi has in fact demonstrated the individual personification in Islamic culture which is an achievement of modern world. Probably, Nassavi wrote his memoir [in the form of letters] to Sa'duddin his cousin and his agent in Nesa to somehow narrate theaccount of the period of his displacement and life in an alien land which shows his understanding of self and individual identity. Apparently, none of the mentioned works has stock to the framework of memoir writing as Nafsat al Masdour has done. The memoir writing approach of Nassavi in his other work underlines the same point.

The second work of Jalaladdin Mengborniis in Arabic (written in 638 hegira). This work discusses the life of Sultan Jalauddin Kharazmshah from the inroad of the Mongols up to his death (628 hegira). The dissemination of news about valorous struggles of Jalaluddin in the western parts of the world of Islam necessitated the introduction of this unique warrior, particularly at a time when the Moguls posed a threat to the Levant and Anatolia.Although at the time of the writing of the book, the increasing wave of Mogul inroads had subsided due to the death of Genghis as well as the internal problems and decline of the Empire of dessert warriors, the shadow of plunder and demolition still loomed large over the Islamic society. Hence, the elite of the Levant as well as the common people were interested in knowing this hero. Among the Iranian secretaries (or administrators) who had sought asylum in the Levant, there was no more qualified writer than Nassavi to write a historical book on the subject. Nouruddin Monshi and Zia al-Mulk had already passed away. Hence, there was no more qualified writer than him in the Jalali broken administration (Sirat Jalaluddin, p. 37, tr. by Naseh, p. 14). Sirat Jalauddin enjoys dual aspects with regard to its content and writing style. It has moved from chronology of unauthentic hearsay to hagiology based on authentic hearsay and observations and then moved to self-centered memoir writing which 
will be discussed below. In other words, Nassavi in the first place has relied on what he has heard from others about the birthplace or base of Tatars or Mongols and surely the number of people in Aleppo who had enough information about this issue was very limited. It seems that he has not even consulted geographical books and has confined his writings to the hearsay and writings of Ibn Athir, some parts of which are not reliable. Some chapters of the book deal with the Khwarazmian Dynasty. Nassavi was expected to offer valuable information on this issue, but unfortunately it is not so. The contents of this part too are very general but reliable. In fact, his account of Mohammad Khwarazamshah is unique. Although the title of the book is Sirat Jalaluddin Mengborni, childhood and adolescence of Jalaluddin have not been reported properly. As a result, this stage of Khwarazmian history is enveloped in a veil of ambiguity and has discussed the life of Jalaluddin after the death of Sultan Mohammad. However, besides worthy reports on the events of the Mongol inroad, it has some other valuable aspects which are as worthy as his description of the Mongol inroad. Nassavi has presented a valuable report on the history of Azarbaijan, which is not even reported in the books written during the Saljukid and the Atabaks of Azarbaijan. Moreover, Sirat Jalaluddin offers unique information about the dispatch of ambassadors and its protocol to the Ismaili court, Ayubi kings and Abbasid Caliphate. This work is unique in this respect, because other works have not paid enough attention to the issue of embassy as a research subject and have explained the issue of embassy and ambassadors in a few sentences only. Indeed, Nassavi, Quoting Totoq, the Ambassador of Khwarazmshah, has precisely explained the protocol of attending the Caliphate court (Sireh 305, tr. by Naseh, 163-168). Regarding the final years of the Khwarazmian dynasty, he has presented an analytical, critical account of the trend of decline and fall of the Khwarazmian Dynasty. In fact, the Sireh book may be considered a text on the trend of decline of the dynasty.

\section{Earlier and Recent Translations of the Sireh}

It may seem prima facie that an explanation about the translation of the Sireh is superfluous in this writing; but, if we bear in mind that the translators have not merely translated the text but have omitted or added some parts, then it would not be redundant. The translators, besides adding their own texts, have intentionally manipulated the text, distorting the historical outlook of Nassavi. Overall, the manipulation of the text by the translators of the Sireh can be divided into three categories: 
1 - Additions: this category includes: the introduction, Persian and Arabic poems, anecdotes, traditions, historical narrations, changing the names of the persons, appendices, new subtitles, adding the name of a poet whose poem had been mentioned by the author without motioning the poet's name, etc. The earlier translator of the book, has made some changes in the introduction of Nassavi, to some extent changing its content. A comparison of the number of poems mentioned in the Sireh and that in the translation indicates that the additions are considerable. The Arabic Sirat has 89 Arabic verses, while the earlier translator has mentioned only 15 verses, omitting the rest. Almost all the remaining Arabic verses belong to other poets such as Malek Nusratuddin, Hamzeh, ruler of Nesa, Shamsuddin Hakim Baghdadi and Abu Tamam. In contrast, this translation contains 46 Persian verses which do not exist in the Arabic text. As a result, the translator has tried to translate them into Persian verses in order to get them close to the original Arabic text. The later translation, i.e. the one by Mohammad Ali Naseh has 15 Arabic verses and 215 Persian ones. The translator has changed the meaning of some of the Arabic verses and has versified some of the prosaic sentences and also added some Persian verses. The omission of one third of the verses has undermined the literary approach of the Sireh. If we take into consideration the number of added or omitted traditions and anecdotes, the changes of this category are considerable.

2 Omissions: There is no omission of the description of events in the later translation. Besides the abovementioned verses, no considerable change is seen compared to the original text. However, there are considerable omissions in the earlier translation. Besides the abovementioned omissions, the omissions can be divided into two categories: the first category includes the omission of some contents of the chapter, like the omission of some parts of the chapters 56, 74 and 87. The second category includes complete omission, like omission of 20 chapters of the 109 chapters of the Arabic text. Given the content of the text, one cannot find a specific logic for the omissions. On the other hand, there is no omission of a full chapter in the later translation (translated by Naseh). Nevertheless, one cannot consider an independent identity for the earlier translation.

\section{Historiographical Insight}

Nassavi was born in an aristocratic rich family. His youthhood coincided with the rise of Sultan Mohammad Khwarazmshah and invasion of Khorasan and his 
birthplace Khazandar Nesa. The attacks of Khwarazmshah created a wave of political and social disorder. Hismiddle age coincided with the inroads and plunders of the Mongols, when Nassavi witnessed the decline and demolition of social structures. AlthoughNassavi did not witness the last victorious inroad of the Mongols led by Hulaku Khan, the political and social disorders inflicted him with tragic pains. While witnessing the rise of Mohammad Khwarazmshah to power, he also was witness to the rapid collapse of the great power that preoccupied his curious mind. He tried to analyze and find the causesof this Great Calamity ["Tammah Kubra" طامه كبرى] (Sireh, p. 37). Hence, his chronology and memoir writing are studied below from this perspective. It should be borne in mind that his works do not contain any theoretical issues of history or historiography. Therefore, his historical approach is inferred from his writings. Evidently, the validity of an explicit intellectual approach by the author is different from that of the one inferred from his writings.Poor methodology among some historians is another problem that applies to Nassavi as well.

\section{1- Critical Insight}

Nassavi is a product of the volatile political trends and rapid military upheavals of his time that have left their impacts on his historiographical approach. A kind of volatility is also observed in his method and approach. His critical insight or approach may be analyzed from two perspectives: criticism of political issues and actions and historical criticism.

In criticism of political issues, Nassavi is a frank writer and has a bitter and cutting language. In fact, the bitterness of his language is a reaction to the unpredictable events of his society. As much as the nature of poetical action of the elite involved in power did not follow a sustainable rational logic, his criticism too lacks a specific delimited framework. In his criticism of political issues, he pays more attention to political and social behaviors than the structures. One reason maybe that at the time of writing the book, he was witness to demolished structures without any hurdle in the way of the destructive inroads of the Mongols and even when he joined the Jalali power system, again he witnessed disorder. Despite serving the Jalaluddin Court for about six years he could not reconstruct the demolished structures or establish new ones. Hence, Nassavi has harshly criticized the political behavior of the Sultan and the courtiers from the harem to army to secretaries in the form of hagiology. In this regard, he may be considered among the historians critical of political issues and expert in analyzing the trend of decline.

Nassavi begins criticism of political issues by criticizing the behavior of Sultan Mohammad and Sultan Jalaluddin Khwarazmshah. The former was accused of 
being coward and naïve (Sireh, p. 104-195; Naseh, 4748), while the latter, despite his traits such as courage and fighting spirit was censured for drunkenness (Sirat, p.377-384; tr. by Naseh 214-215, 211). In criticizing the poetical power of Khwarazmian kings, he harshly criticized the ambivalent attitude of Turkan Khatun, the powerful wife of Sultan Mohammad, blaming her for the schism in the structure of monarchy. He accuses her of shrewdness, cruelty and murder of a number of detained princes which left her "eternal notoriety on the pages of history" (Sirat, p. 95-100; tr. Naseh 42). On the other hand, he praises her (Ibid., 44). Not only he repeats the same ambivalence about Tarkan Khatun and other sultans but he also follows the approach about other ministers (viziers) (Sirat, p. 202-204; tr. Naseh, 202-203). One may perceive that this ambivalence stems from the honesty of the historian, but his admiration encompasses a small volume of his writings, while censures and negative attitudes are predominant. There is almost no praised person in Nassavi's historiography. Perhaps the main reason for this pessimism is the implicationsand consequence of currents, fall of governments and demolition of society. However, he does not show his role in the disintegration of the system and tries to somehow acquit himself (Sirat, 251-252; tr. Naseh, pp. 176177, 132-133). Nassavi's critical approach at times pushes him towards lopsided and biased judgment abut the incentives of the actors of the social arena. As a result, under the influence of this approach, he has depicted an imbalance picture of the political behavior and structure of the society. In this approach, he divides the society under the rule of Khwarazmian into two groups: the Mesopotamians and Khorasanis, with an almost positive outlook towards the Khorasanis. However, contrary to Nezam ul Mulk (who was pessimistic about Iraqis), he is not fully pessimistic about the Mesopotamians, but is not happy with their political behavior. This approach applies to his ethnic attitude as well. He is not optimistic about the Turk military servicemen and secretaries. If he sometime praises a Turk commander, it is an individual case. He maintains that one of the reasons for the fall of the Khwarazmian Dynasty was the disobedience of the elite, particularly the army commanders (Naseh, 192-213). His critical approach at times pushes him towards satire, lampoon and censure and even unethical and nasty insults, sparing no one (Nafsat al Masdour, p. 62-63, 75-86).

\section{2 - Elitist Approach}

Like many other historians of his time, Nassavi maintains that the elite played a crucial role in the rise and fall of dynasties to power. In his attitude towards power, he establishes a connection between the behavior of the elite and power of monarchy. In his opinion, the more powerful the institution of monarchy and the king, the more convergence will be the behavior of the political elite, and, on the contrary, the weaker the Sultana and the monarchy, the more divergence the 
behavior of the elite. Nassavi's analysis of the decline of Khwarazmian is based on the above assumption. He maintains that the elite in their behavior prefer their immediate personal interests to those of the immediate state interests. As a result, he argued, the elite not only were in conflict with each other, but also, were indifferent towards the fate of the monarchy. Absence of consensus among the elites damaged the power structure often pitting the elite against each other, undermining a unified stance amongst them. Their temporary unity was based on their personal gains not the interests of the monarchy. Hiscriticism has not spared the performance of Sharafuddin Vizier, Jamaluddin Araqi, Zia al Mulk, ruler of Nesa, Sharafuddin Ali Tafreshi, Urkhan, Uterkhan, etc. (Nafsat al Masdour , 75-86; Sirat, 225-227, 269-270; tr. Naseh 116-119, 205).He has demonstrated that the fall of the Khwarazmian more than being a result of the Tatar inroad was a consequence of rebellion of the elite against the rulers and lack of respect for the luminaries. He also clearly shows that the elite played an effective role in the unfolding of the developments. Hence, a major chunk of his book is allocated to the elucidation of the political behavior of the elite. Although by writing the Sirat Jalaluddin he aimed to highlight the role of the Sultan and monarchy, in practice, he has engaged in memoir writing and the role of political elites, secretaries and army commanders and servicemen in the ruling system.

Nassavi has not confined his writing to the role of the elite in power structure. In his critical approach, he has censured the common people as well. Commenting on the anti-Khwarazmian movement of the downtrodden people of Ganja, he introduces the people as such: "The common people are just like animals that follow each other and thousands of them follow one.” (Sirat, 270-272, Naseh, 205).

\section{3 - Monarchist Approach}

Political historiographies that were often written at the court, secretariat or by political elite or scholars, normallyfocused on the monarchy and the Sultan as the center of attention. In fact, monarchist approach had become the fundamental principle of historiographical approach in the traditional period. This approach tried to identify the positive and negative developments as an outsider observer of the monarchy. Although, like his predecessors, Nassavi too thought and wrote within the framework of his monarchist discourse, in his dealing with the Sultan he sometimes had a critical approach as well. He made a delicate distinction between the monarchy as a durable institution and sultan as an agent who is exposed to wrongdoing and committing mistakes. However, in his intellectual paradigm, Nassavi sometimes considered the king's mistakes as an "outcome of doomed events" and "predestined divine fate" that the Sultan could not evade. Nassavi 
believed that "the Persian kingdom was a property obtained by sacrifice of lives, but has become a widow now." (Nafthat al-Masdour, 85).

Contrary to Utbi and Zahiruddin Neishaburi, Nassavi is not a historian of the era of flourishing, who considers the preservation of the status quo contingent upon the survival of the Sultan. He is a product of volatile political and military circumstances and an observer of the rapid fall of political power which had been turned into a great kingdom with the same speed. He was a witness to the premature rise and early fall of the Khwarazmian Dynasty. The prevailing thought did not work in the said political and military circumstances. Nassavi laments the fall of religion and state that had intertwined in the political thought of Iran. Using some bombastic, embellished phrases, he writes: "Religious rites and rituals have become superficial. The foundations of Islam have been totally undermined; there is no mercy in the land of grace, there is no one to give warmth to the quarters of magnanimity; rulers have become killers; the ways have turned into battlefield, the rules and regulations have been violable; laws have been sunken to oblivion; devils have taken the place of secretaries; the schools have dilapidated; sessions of learning have turned into bastion of war, gardens have been ruined, the atmosphere is suffocating." (Nafsat al Masdour, 94-95).

He also speaks of the duality in speech and acts of the elites, particularly the army commanders, towards the monarchy and the monarch as a reason for the unfolding of developments and collapse of the Khwarazmian Dynasty. He calls the army commanders as a "group of coward with ill-wishers" who push the Sultan to do impossible things (Sirat, 270-272; Naseh, 205). Quoting Jalaluddin, he writes: "They, i.e. the Turk emirs and commanders of the army and divisions have decided to do things impossible and have been enchanted with illusion and pinned hopes on something wrong and want to evade fighting the enemy and are not ready to bear the burden of war and have disturbed my peace of mind (deliberation) due to their greed." (Sirat, 272; tr. Naseh, 206). In nutshells, Nassavi is a historian who is expert in analyzing the decline of Khwarazmian Dynasty. His complicated analysis and explanation focuses on the behavior of Khwarazmian courtiers and military commanders.

\section{Nassavi’s Historiographical Method}

The historians of Nassavi era, including his predecessors and posteriors, were not methodological historians, but they were not devoid of organized methodological concerns. They gained their methodology either through imitating others, acquisition, innovation or manipulation of the predecessors' methods. Nassavi did 
not have an organized methodology. Hence, just like his thought, his methodology too should be inferred from his historical text in order to reconstruct his methodological and intellectual order. Hence, in order to achieve this goal, some features of his methodological approach such as style, sources, edition of tradition, integration, discontinuity and continuity latent in the text are studied below. These features together shed light on his historiographical methodology.

\section{1 - Writing Style}

Nassavi is a historian and literarianwho wrote his historical literary text by employing literary devices in technical, complicated and bombastic Arabic language. His work contains literary devices (such as poem, anecdote, allegories and prose). Given the relationship between the form and content, one may say that there is a kind of duality in historiography. This duality is the outcome of two kinds of historical writings: one, Nafsat al Masdour, in which literary aspects dominate the historical dimensions. The highlighting of literary aspects of a historical text undermines the trend of historical narration and representation of historical facts becomes complicated through layers of literary outlook. As a result, literary aspects dominate every other dimension. In other words, the historian forgets that he is writing a historical text and hence he tends towards memoir writing instead of writing historical events. It seems that Nassavi himself did not intend to write a historical account of his time, rather he intended to write "a resentment report". He writes: "I have decided to write some chapters on resentment about the misfortunes" (Nafsat al Masdour, p. 4). Hence, Nassavi appears as a literarian memoirist whose report of the events is predominantly enveloped in literary devices.

Nassavi, in his other book, i.e. Sireh Jalaluddin Mengborni, appears as a historian of historical events focusing on the speeches and actions of Sultan Jalaluddin. Although Nassavi is a literarian and historian who has undertaken writing, in this book he does not appear as a literarian. In this work, he oscillates between a chronologist who relies on hearsay and anobserving reporter and a memoirist. This oscillation has left its impacts on his writing style as well. As a chronologist, his writing is affected by the sources he has studied or heard, which is mainly under the influence of the writing style of Ibn Athir. As an observer, his writing gets closer to literary features and aesthetic aspects dominate epistemological approach, but soon chronological approach dominates his writing. However, as a memoirist, his writing and text tends towards simplicity without much embellishment. In fact, in the Sireh, he writes whatever he has done, whose style is story writing without intricacy and bombast. The author in this book appears as a precise historian who pays attention to the details through a causal approach. 
One of the reasons for textual multiplicity of the hagiology of Nassavi lies in the sources he used, because the said sources are not homogenous in their forms, contents and natures. Although he has not mentioned all the sources he has used, his sources may be divided into several groups: documents, including official communications andletters, and historical books such as Ibn Athir's Al-Kamil (Naseh, p. 28) as well as literary books (divans, anecdote and allegory books, treatises, etc.), hearsay and observations. Among the historical books, hearsay and observation have played a stronger role compared to historical books in his historiography. However, he has referred to Ibn Athir in many places: "when I read the Kamel, compiled by Ali bin Muhammad bin Abd al Karim, known as Ibn Athir, I found it unique in discussing the condition of the nations, particularly that of the Iranians, and it truly deserves to be named Kamil (Perfect)." (Naseh, p. 13). He has also mentioned certain political actors including Sharaf ul Mulk, the Vizier, Sultan Jalaluddin, Rabibuddin Vizier Atabak Uzbak, Qazi Mujibuddin Umar bin Sa'd Kharazmi, Totoq, son of Urkhan, etc. and has tried to mention his source with mentioning his name or some time as ananonymous observer. For instance: "he himself told me", "he narrated for me", "a person who had witnessed the tragedy told me" (Sirat, p. 67; tr. Naseh, 21, 23, 24). However the main chunk of the book is composed of his personal observations. In validification of two kinds of narrations, i.e. the heard narration and the observed narration, he gives priority to the latter. He writes: "Yes, it is true that there are differences between hearsay and observation and between news and fact... in this regard, I write only what I have observed or I have heard from a person who has personally observed and will not write anything other than this" (Sirat, 36-37, Naseh, p. 13).

\section{2 - Editing of the Narrations}

Following the method of predecessors, in order to use primary sources, he at least edited the narrations. Nassavi employed the following measures in his historical report: summarization of reports, attempts to protect the verbal language, omission of parallel reports, omission of irrational and unacceptable hearsay and selection of correct narration on the basis of historical understanding. The writing and reporting styles of Nassavi were a function of his source. For instance, in the first parts, which he has mainly heard from Ibn Athir, he has collected the reports of the far distance just like those of the birthplace of the Tatars, which is a kind of general imprecise statements. But when he reports what he has heard from people who were close to the event regarding its time and space, he is more narrative and precise and also narrates in the form of dialogue. Hence narration in the form of dialogue is one of the significant features of Nassavi's historiographical method. For instance: "Nezam ul Mulk told me [Qazi Mujiruddin Umar]... I said...He accepted...I replied that...(Sirat, 65-69, Naseh, p. 20). This style is also used in 
Beihaqi, but it has been used in a simple, story-writing method in Nassavi's work, granting a unique advantage to his book.

\section{3 - Textual Continuity and Discontinuity}

In the introduction of his book, Nassavi very humbly states that he is not qualified to write the history of Khwarazmian Dynasty, but since most of the writers had been killed "I decided to undertake this task, considering it an obligation, otherwise given my rent heart and frustration as well as weak thought and poor qualification in writing a book, I would not have done so." (Sirat, 36-37; Naseh, p. 14). Without using the word continuity, he has employed certain measures to accomplish this great task: one of them is: using the method of topical chronology. But he has failed to protect continuity in writing. In this regard, he starts writing an account, completes it and then starts the writing of another one. At times these events were not continuous but parallel to each other. In order to organize his writing, the historian sometime has to start the events from a far away point which are not congruent with regard to their contents and time of occurrence. In narration, he follows topical narration, which does not precisely follow historical sequence. This is a specific style in his work that has its particular order. In expression of narrations, he first discusses the background and context of the events and then explains them. It seems that he has been influenced by Ibn Athir with regard to this style, while Ibn Athir is an annualist, butwhen he narrates an event of a specific year, he narrates the backgrounds and contexts of the event from previous years in one place. However, Nassavi has used this method in topical narration. Another feature of Nassavi's historiography is narration within narration (Sirat, 64-65; Naseh, 27-28). Time is another element in Nassavi's historiographical methodology. Although one cannot conceive the history without time, for time is an essential element of history, in Nassavi's historiography, the element of time is often neglected as an organizer and explainer of the events. Inattention to organized time leads to a kind of methodological disorder in historical sequence of events. This issue has left a negative impact on precise explanation of causal relationship between phenomena in Nassavi's text. He rarely states the history of events. Either due to lack of access to documents and authentic sources or due to reliance on oral narrations or due memoir writing, Nassavi rarely tries to mention the date of events. Lack of statement of the date of events has led to condensation of the time of events in one narration.

The way of comparison of historical narrations and data is another feature of Nassavi's historiography, which has been mainly used with regard to positions and jobs. Sometimes he narrates the functions of jobs during the Siljukid era. He has also used comparison for studying events. This kind of comparison keeps the mind 
of reader active, leaving the conclusion about the nature of events to the reader, while refraining from their frequent repetition. For instance, he writes: "Well, this was the prevailing situation in Khorasan, while the situation in Mazandaran and Iraq can be considered similar and there is no need to go into the details". (Naseh, p. 90).

Another feature of Nassavi's work is that in order to preserve the continuity of narration, he has gone beyond mere expression of incidents and penetrated the back of mind of the actors, explaining the thoughts and political ideas that he assumed were in the back of mind of the actors. He used this method often when he intended to analyze the event or the incentives behind them. (Sireh Jalaluddin Mengborni, Arabic text, pp.55-56; Naseh, 23, 25).

\section{Conclusion}

Nassavi is among the pioneers of historiography of early seventh century of Mongol historiography and is an intermediate like between historiography of the Levant (Al-Kamel of Ibn Athir) and historiography of Joveini. He was influenced by Ibn Athir but left his impact on Joveini. However, as a literarian and historian, he has not been able to produce an integrated work regarding its form and content. From chronology, he has tended towards hagiology and then towards memoir writing. As a result of this fluctuation the level of hagiology has declined. For instance, the sentences under the title of Sireh (conduct), often explain the position of Sultan Jalaluddin. But immediately, he engages in memoir writing or chronology. As a result, this kind of explanation of the issues has prevented the text from having an integrated structure. However, it does not mean that Nassavi's historiography should be underestimated or undervalued. As a matter of fact, Nassavi's narratory, is different from that of many historiographers or even hagiologists. The most important achievement of Nassavi's historiography is transition from chronology to memoir writing.

\section{References and notes:}

Hassanzadeh, Ismail (2007). Historical Perspective and Historiography of Emaddudin Kateb Isfahani, Journal of Humanities, Al-Zahra University,(65), 21-55.

Nassavi, Shahabuddin Muhammad Zydari (2006). Nafsat al Masdour, edited by Amir Hossein Yazdgerdi,Tehran: Tous Publishers.

Nassavi, Shahabuddin Muhammad Zydari (1953). Sirat Jalaluddin Mengborni, edited and published by Hafez Ahmad Ahmadi, Cairo. 
Nassavi, Shahabuddin Muhammad Zydari (2005). Sirat Jalaluddin Mengborni, Editing of introduction and appendices by Mojtaba Minavi, Entesharat Elmi va Farhangi.

Nassavi, Shahabuddin Muhammad Zydari (1987). Sireh Jalaluddin or Tarikh Jalali, tr. by Mohammad Ali Naseh, assisted by Khalil Khatib Rahbar, Tehran: Entesharat Sa'di.

\title{
Summary
}

\section{Historiography of Shahabuddin Muhammad Zydari Nassavi: From Chronologist to Memoirist}

\author{
Hassan Hazrati \\ University of Tehran, Iran
}

Historiography of Nassavi is one of the late Arabic writings by an Iranian literarian and historianwho has left two important works, i.e. Nafsat al Masdour and Sirat Jalaluddin Mengborni. The first one's approach is memoir writing, with anembellished and intricate style. The second one's approach is hagiology writing style, but ends up in a memoir writing approach. Under the prevailing turbulent circumstances of his time, Nassavi tries to analyze the pathology and decline of the Khwarazmian era. These works are among the first few historiographical studies of the Mongols. Nassavi does not explicitly refer to his historiographical approach. Hence, a researcher has to find out his thought and method through the lines of his writings. Attempts have been made in the present study to analyze Nassavi's historiographical thought as well as his method which is based on hearsay and observation.

Keywords: Shahabuddin Muhammad Zydari Nassavi, Sireh Jalaluddin Mengborni, Nafsat al Masdour, Khwarazmian historiography, Mongol historiography 